\title{
Siloxane removal for biogas purification by low cost mineral adsorbent
}

\section{Sandra Pioquinto García ${ }^{a}$, Luis Ángel Garza Rodríguez ${ }^{c}$, Diana Bustos Martíneza , Felipe} de Jesús Cerino Córdova ${ }^{a, 1}$, Eduardo Soto Regalado ${ }^{a}$,Sylvain Giraudet ${ }^{b^{*}}$, Nancy Elizabeth

\section{Dávila Guzmán ${ }^{\mathrm{a}^{*}}$}

${ }^{a}$ Universidad Autónoma de Nuevo León, UANL, Facultad de Ciencias Químicas.

Av. Universidad S/N, Cd. Universitaria, San Nicolás de los Garza, Nuevo León, CP 66455, México.

'École Nationale Supérieure de Chimie de Rennes, UMR CNRS 6226,11 Allée de Beaulieu, 35708 Rennes, Francia

${ }^{\mathfrak{c}}$ Instituto Tecnológico de Estudios Superiores de Monterrey, Departamento de Química y Nanotecnología, Ave. Eugenio Garza Sada 2501 Sur, Monterrey, Nuevo León, CP 64849,

\section{México}

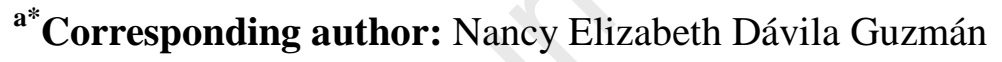

Phone number: $\quad$ 52-8183294000, ext. 3475

Fax number: $\quad$ 52-8183294000, ext. 6282

E-mail: nancy.davilagz@uanl.edu.mx

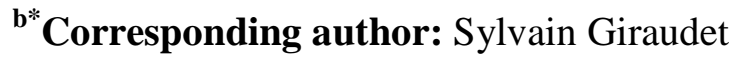

Phone number: +33 (0)2 23238015

E-mail: sylvain.giraudet@ensc-rennes.fr

${ }^{1}$ Current address for Felipe Cerino: Universidad Autónoma de Nuevo León, UANL, Facultad de Ingeniería Mecánica y Eléctrica. Av. Universidad S/N, Cd. Universitaria, San Nicolás de los Garza, Nuevo León, CP 66455, México. 
Sandra Pioquinto-Garcia: Investigation, Writing- Original draft, Formal analysis; Nancy Davila-Guzman: Conceptualization, Methodology, Writing- Review \& Editing, Project administration, Funding acquisition; Luis Garza-Rodriguez: Conceptualization, Funding acquisition; Sylvain Giraudet: Methodology, Formal Analysis, Supervision; Diana Bustos-Martinez: Validation, Resources; Felipe Cerino-Cordova: Writing- Review \& Editing, Eduardo Soto-Regalado: Funding acquisition, Methodology. 


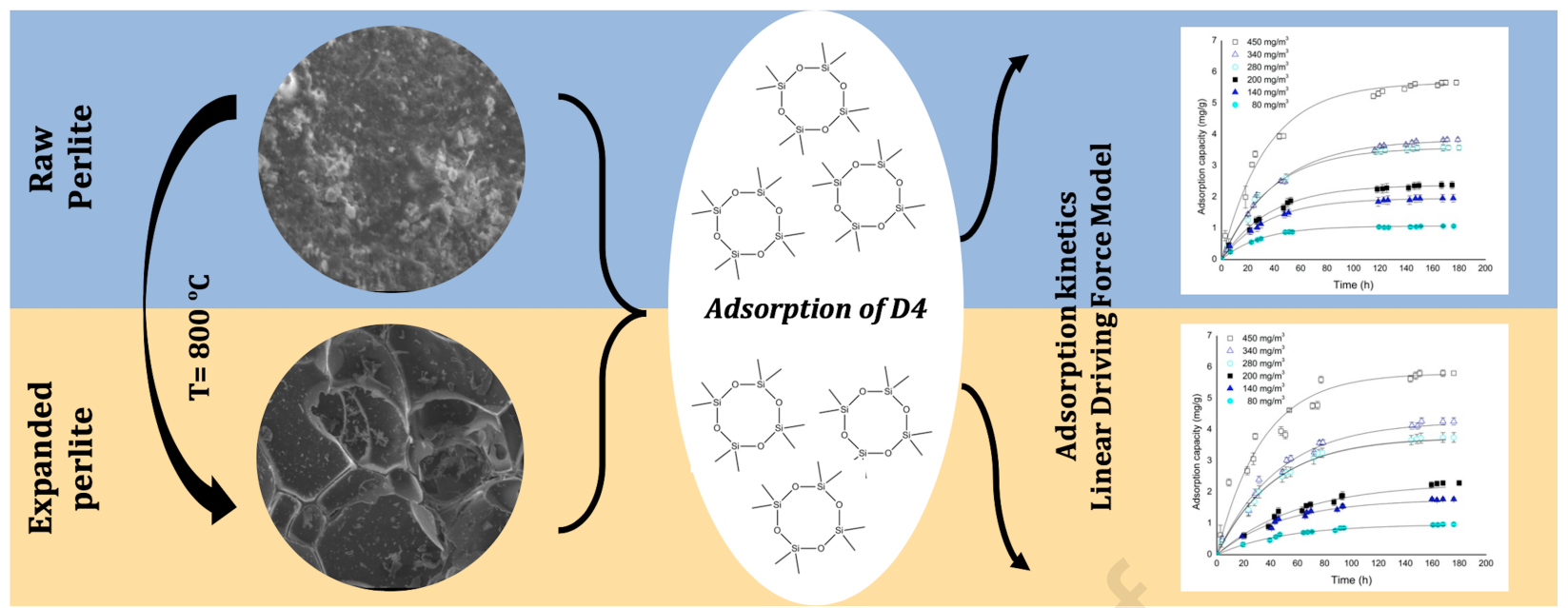




\section{ABSTRACT}

The potential use of raw and expanded perlite as low-cost adsorbents for biogas purification has been investigated. The thermal expansion of perlite causes a reduction in the density of silanol groups from 2515.43 to $653.75 \mathrm{OH} / \mathrm{nm}^{2}$; in contrast, the specific surface area of perlite increased two-fold due to the thermal expansion. To determine the equilibrium adsorption capacity and the adsorption kinetics batch experiments were conducted. The adsorption capacities are in the following order: activated carbon (6.8 $\mathrm{mg} / \mathrm{g})>$ silica gel $(6.6 \mathrm{mg} / \mathrm{g})>$ expanded perlite $(5.81 \mathrm{mg} / \mathrm{g})>$ raw perlite $(5.6 \mathrm{mg} / \mathrm{g})$ when compared at the same experimental conditions. The equilibrium adsorption data showed that perlite can be used to reduce the octamethylcyclotetrasiloxane concentration below $28 \mathrm{mg} / \mathrm{m}^{3}$, as recommended by leading manufacturers. The adsorption kinetics of octamethylcyclotetrasiloxane onto raw and expanded perlite followed the Linear-Driving Force model suggesting that the mass transfer is the ratecontrolling step. In addition to its low cost, expanded perlite has the advantage of requiring lower desorption temperature $\left(200^{\circ} \mathrm{C}\right)$ for regeneration in comparison to the reported values for activated carbon (> $400 \stackrel{\circ}{\circ}$ ) and fast desorption kinetics (20 min), which could contribute to a cleaner production of biogas.

Keywords: Octamethylcyclotetrasiloxane; biogas; perlite; adsorption; isotherm; kinetics Abbreviations

a Elovich parameter 


\begin{tabular}{|c|c|}
\hline $\mathrm{b}$ & Elovich parameter \\
\hline$A C$ & activated carbon \\
\hline Co & initial concentration \\
\hline $\mathrm{C}_{\mathrm{e}}$ & concentration at equilibrium \\
\hline D4 & octamethylcyclotetrasiloxane \\
\hline$d$ & diameter of adsorbent particle \\
\hline Ds & effective diffusion coefficient \\
\hline EP & expanded perlite \\
\hline $\mathrm{K}_{\mathrm{L}}$ & effective mass transfer coefficient \\
\hline $\mathrm{K}_{\mathrm{R}}$ & Ritchie kinetic rate constant \\
\hline LDF & linear driving force \\
\hline$\dot{m}_{a d s}$ & adsorbent mass per hour \\
\hline$p_{\text {ads }}$ & price of the adsorbent \\
\hline$q$ & adsorption capacity at time $t$ \\
\hline$q_{e}$ & adsorption capacity at equilibrium \\
\hline$Q_{b g}$ & biogas flow rate \\
\hline $\mathrm{R}^{2}$ & coefficient of determination \\
\hline $\mathrm{RP}$ & raw perlite \\
\hline SE & standard error \\
\hline$S G$ & silica gel \\
\hline to & Elovich constant \\
\hline WWTP & wastewater treatment plant \\
\hline$\alpha$ & effective volume ratio \\
\hline
\end{tabular}




\section{Introduction}

The United Nations, in 2015, proposed promoting the use of renewable energy as a priority of the 2030 Agenda for Sustainable Development (United Nations, 2015), since there is great potential to use clean and renewable energy in the world, especially in the use of biomass for the production of biofuels such as bioethanol, biodiesel, and biogas (Tabatabaei et al., 2020). Biogas is generated from organic matter in an anaerobic environment (Santos et al., 2018). In the world, the United States (US) and Europe are the main producers of biogas (Scarlat et al., 2018). According to the American Biogas Council, the US has a potential biogas production from wastewater treatment plants (WWTP) and landfills. WWTP could generate 2.97 billion $\mathrm{Nm}^{3} /$ year of biogas to make 5.6 billion $\mathrm{kWh}$ of electricity/year. While the biogas from landfills could amount to 7.47 billion $\mathrm{Nm}^{3} /$ year to produce 22.5 billion $\mathrm{kWh}$ of electricity/year (American Biogas Council, 2014). In Europe, Germany is positioned as the leader in the production of biogas, with 94 biogas plants and 120 biogas upgrading plants (including landfill plants) and upgrading capacity of 1.79 billion $\mathrm{Nm}^{3} /$ year (Ullah Khan et al., 2017). The Mexican biogas production from WWTP is estimated to be 0.14 billion $\mathrm{Nm}^{3} / y e a r$, which could produce 0.332 billion kWh of electricity/year (IMTA, 2016). The landfill gas potential is estimated to be 4.97 billion $\mathrm{Nm}^{3} / \mathrm{year}$, considering 24.91 million tons of waste in landfills (REMBIO, 2012). 
The biogas composition is highly dependent on the origin and the production conditions such as microorgnisms, temperature, and impurities (Chaemchuen et al., 2016, Tabatabaei, et al., 2020). Biogas is generally a mixture of $50-70 \mathrm{v} \%$ methane, $30-50 \mathrm{v} \%$ carbon dioxide, and $<6 \mathrm{v} \%$ residual compounds such as water vapor, hydrogen sulfide, and siloxanes (Poloncarzova et al., 2011). Hydrogen sulfide and siloxanes must be removed from the biogas to increase the calorific value and avoid damage to the combustion system (Álvarez-Flórez and Egusquiza, 2015, Kapoor et al., 2020). Removal of hydrogen sulfide can be achieved by biological treatments that are inexpensive and environmentally friendly (more extensive review on removal of hydrogen sulfide by biological treatment can be found in Khoshnevisan et al., 2017). On the other hand, the siloxanes are undesirable in a gas combustion system due to the formation of silicon dioxide (Álvarez-Flórez and Egusquiza, 2015). The silicon dioxide solid deposits damage parts of the combustion system such as pistons, cylinder heads, and valves (Matsui and Imamura, 2010) causing low efficiency and high repair costs (Ajhar et al., 2010). In WWTP and landfills, typical concentrations of siloxanes in biogas are between 1-400 mg/ $\mathrm{Nm}^{3}$ (Dewil et al., 2006), where octamethylcyclotetrasiloxane (D4) is the common siloxane compound found (Tran et al., 2019a). Although, there is no legislation to regulate the amount of siloxanes to avoid damages in the combustion systems, some recommendations had been made for limiting the concentration of siloxanes in biogas from 0.3 to $28.0 \mathrm{mg} / \mathrm{m}^{3}$ (Gaj, 2017).

There are two types of methods for eliminating siloxanes in biogas: pretreatment methods and post-purification methods. The first might include direct sludge purging processes or heat treatment before anaerobic digestion. The second type, which is the 
primary method for commercial applications, includes technologies such as adsorption, absorption, cryogenics, filtration by membrane, catalysis, and biological processes (Wang et al., 2019). Several publications detail the techniques for eliminating siloxanes by post-purification methods in which the efficiencies, advantages, and disadvantages are indicated (Gong et al., 2015; Ruiling et al., 2017; Shen et al., 2018). In general, the use of some post-purification techniques could reach removal efficiencies greater than $90 \%$, to achieve such high efficiency implies that the cost of investment and operation would also be high.

The most common biogas purification technology is adsorption, the use of alumina, silica gel, activated carbon, zeolites, and polymeric adsorbents have been reported for removal of siloxanes. Note that the activated carbon is included in all comparisons because this adsorbent is the most used in the biogas purification process (CabreraCodony et al., 2018). The adsorption process with activated carbon still has some drawbacks associated with the high regeneration temperatures $\left(400-1000{ }^{\circ} \mathrm{C}\right)$, incomplete desorption (Giraudet et al., 2014) and, consequently, a high cost (SantosClotas et al., 2019). This study aims to evaluate a low-cost mineral as a new material for siloxane removal, which has a silicon dioxide composition similar to silica gel, approximately $80 \%$ (Alkan et al., 2005), and it is three times cheaper than activated carbon.

\section{Materials and Methods}

2.1 Adsorbent and characterization 
Raw Perlite (RP) and Expanded Perlite (EP) were provided by TERMOLITA (Mexico), PICACTIF NC 60 activated carbon was supplied by PICA Corp. (France), and silica gel was supplied by PROLABO (France). The materials were sieved using a mesh No. 20, and the moisture was removed at $108^{\circ} \mathrm{C}$ for 24 hours in a Memmert $\Theta$ oven.

The analysis of Fourier transform infrared (FTIR), X-ray diffraction (XRD), and thermogravimetry, required RP and EP as powders. Thus, a Rock Lab Benchmill 50 vibratory mill was used to grind them. For the adsorption tests, nitrogen with purity > $99.995 \%$, hydrogen with purity $>99.999 \%$, and synthetic air $\left(\mathrm{O}_{2} 20 \% \pm 2 \%\right)$ were supplied by the company Air Liquide (France).

The crystalline structure of the RP and EP was evaluated via an X-ray powder diffractometer Siemens brand model E04-0012. The functional groups on the surface of $\mathrm{RP}$ and EP were identified using an FTIR analysis performed in an Agilent Technologies Cary 630 FTIR device, from 4000 to $400 \mathrm{~cm}^{-1}$ at a resolution of $16 \mathrm{~cm}^{-1}$ triangular apodization type, Mertz phase-type, with a $\mathrm{KBr}$ disk being used as a background. The morphology of RP and EP was studied by using the images obtained by scanning electron microscope (SEM) with a JSM 6301F (JEOL®) equipment for classical images, and a JSM 6400 (JEOL®) coupled to a power dispersion spectrometer (EDS) for the elemental analysis of the surface. The specific surface area of RP, EP, and silica gel were obtained by analyzing the $\mathrm{N}_{2}$ adsorption-desorption at $77 \mathrm{~K}$ carried out in an Autosorb-1-MP Quantachrome Instruments ${ }^{\circledR}$ (from ENSCR, France) and by using the BET equation.

The thermogravimetric analysis (TGA) of RP and EP was carried out to determine the thermal stability of the adsorbents; a TA instruments Q500 thermogravimetric analyzer 
was used with a temperature range from $50-850{ }^{\circ} \mathrm{C}$, a heating rate of $10{ }^{\circ} \mathrm{C} / \mathrm{min}$, and $\mathrm{N}_{2}$ atmosphere. The density of the silanol groups was estimated from the thermal analysis following the procedure reported elsewhere (de Farias and Airoldi, 1998). Briefly, the mass of silanol groups was obtained from the mass loss detected from the thermogravimetric curve. This mass loss is due to the condensation of two silanol groups. Then, the density of silanol groups is calculated by dividing the amount of silanol groups by the perlite surface area.

\subsection{Adsorption experiments.}

The adsorption tests were carried out at six siloxane D4 initial concentrations. First, 20 $\mu \mathrm{L}$ of D4 (analytical grade, liquid, $98 \%$ purity, Sigma-Aldrich) were allowed to volatilize in a $2 \mathrm{~L}$ glass flask. Then, different amounts of $\mathrm{D} 4$ vapor $(18-104 \mathrm{~mL})$ were taken to be injected into a second glass flask ( $2 \mathrm{~L})$, previously flushed with dry air, to obtain the desired concentration of $\mathrm{D} 4$, ranging from 80 to $450 \mathrm{mg} / \mathrm{m}^{3}$. The adsorption tests were carried out in $2 \mathrm{~L}$ glass flasks, placing $0.154 \mathrm{~g}$ of adsorbent material into a steel basket inside the flask, the particle size used in all experiments was $1 \mathrm{~mm}$, constant temperature $\left(25{ }^{\circ} \mathrm{C}\right)$, pressure of $1 \mathrm{~atm}$, and a D4 initial concentration from 80 to 450 $\mathrm{mg} / \mathrm{m}^{3}$ (Figure S1). Each flask was stirred at $700 \mathrm{~min}^{-1}$ for $170 \mathrm{~h}$ to ensure the equilibrium was reached. During adsorption experiments, samples were taken for further analysis of concentration by using gas chromatography. Each sample was injected into an HP 6890 Series II gas chromatography system with a flame ionization detector (FID) to measure the concentration of siloxane D4. The column used was an HP-624 Special Analysis capillary column $(30.0 \mathrm{~m} \times 0.25 \mathrm{~mm}$ inner diameter $\times 1.40 \mu \mathrm{m}$ 
film thickness). The inlet temperature was set at $150^{\circ} \mathrm{C}$, oven at $145^{\circ} \mathrm{C}$, and detector at $250{ }^{\circ} \mathrm{C}$. The $\mathrm{N}_{2}$ was used as carrier gas at a flow rate of $2.3 \mathrm{~mL} / \mathrm{min}$ and $17.71 \mathrm{psi}$. The injected volume was $0.5 \mathrm{~mL}$ with splitless, and the duration of each analysis was 3.4 min. The adsorption capacity was obtained by the mass balance, using Eq. (1):

$q=\frac{\left(C_{0}-C\right) V}{m}$

Where $q$ is the adsorption capacity $(\mathrm{mg} / \mathrm{g}), C_{o}$ is the D4 initial concentration $\left(\mathrm{mg} / \mathrm{m}^{3}\right), C$ is the D4 concentration at time $t\left(\mathrm{mg} / \mathrm{m}^{3}\right), V$ is the volume $\left(\mathrm{m}^{3}\right)$, and $m$ is the adsorbent mass $(\mathrm{g})$. Batch adsorption experiments were carried out by triplicate (coefficient of variation $<7 \%$ ) and the adsorption capacity was obtained by the average value of the three tests.

\subsection{Adsorbent Regeneration Studies}

The regeneration of EP was studied by carrying out an adsorption experiment with $7.0 \mathrm{~g}$ of EP at an initial concentration of $450 \mathrm{mg} / \mathrm{m}^{3}$ and $25{ }^{\circ} \mathrm{C}$, as described in Sec. 2.2. When the equilibrium was reached, the flask was insulated and placed on a heating plate at $200{ }^{\circ} \mathrm{C}$ for the desorption of $\mathrm{D} 4$ for $10 \mathrm{~h}$. Several samples were taken for further concentration analysis on GC to obtain the desorption kinetics.

\subsection{Mathematical models}

For dilute systems, the Henry isotherm model is used (Eq. 2), where there is a linear relationship between the equilibrium concentration and the equilibrium adsorption capacity (Cooney, 1998).

$q_{e}=K C_{e}$ 
where $K$ is the Henry constant $\left(\mathrm{m}^{3} / \mathrm{g}\right), C_{e}$ and $q_{e}$ are the D4 concentration $\left(\mathrm{mg} / \mathrm{m}^{3}\right)$ and adsorption capacity $(\mathrm{mg} / \mathrm{g})$ at equilibrium, respectively.

For the adsorption kinetics, four models were used to predict the evolution of the adsorption capacity through time. The Elovich kinetic model (Eq. 3) was developed for gas-solid adsorption systems (Russo et al., 2017) and establishes that the active sites of the adsorbents are heterogeneous and the mass transfer resistance to be negligible. $q=\frac{1}{b} \ln \left(t+t_{o}\right)-\frac{1}{b} \ln \left(t_{o}\right)$

Where $q$ is the adsorbed amount at $\mathrm{t}(\mathrm{mg} / \mathrm{g}), b$ is the Elovich constant $(\mathrm{g} / \mathrm{mg}), \mathrm{t}_{o}=1 / \mathrm{ab}, a$ is the initial adsorption rate $\left(\mathrm{mg} / \mathrm{g}^{*} \mathrm{~h}\right)$ and $t$ is the time $(\mathrm{h})$.

The Ritchie kinetic model (Eq. 4) considers adsorption at specific sites on the surface of a solid (Ritchie, 1977). The rate of adsorption depends on the fraction of sites that are unoccupied at time $t$ :

$\frac{q_{e}^{n-1}}{\left(q_{e}-q\right)^{n-1}}=(n-1) k_{R} t+1$

where $q_{e}$ and $q$ are the adsorption capacity at equilibrium $(\mathrm{mg} / \mathrm{g})$ and the adsorption capacity $(\mathrm{mg} / \mathrm{g})$ at time $t$, respectively. $n$ is the number of sites on the surface occupied by an adsorbed gas and is equal to two for second-order reaction kinetics (Altindal et al., 2014), $k_{R}$ is the kinetic rate constant $(1 / \mathrm{h})$, and $t$ is the time (h).

The mass transfer models consider the external mass transfer resistance or the intraparticle diffusion as the rate-controlling steps. Despite this physical mechanisms, among the mass transfer models most reported in the literature to describe the adsorption kinetics of gases and liquids in solid materials (such as carbon dioxide, nitrous oxide, and acetylene), are the linear driving force (LDF) model (Yao and Tien, 
1992) and the Crank model (Crank, 1975), which consider a single adsorption rate. This rate of adsorption lumps together the external and internal mass transfers.

The LDF model (Eq. 5) assumes that the adsorption rate is proportional to the difference between the average concentration of adsorbate at the gas-solid interface $\bar{C}^{*}(t)$ and the average adsorbate concentration in the adsorbent particle $\bar{C}(t)$ (Sircar and Hufton, 2000):

$\frac{d \bar{C}(t)}{d t}=k_{L}\left[\bar{C}^{*}(t)-\bar{C}(t)\right]$

The analytical solution of the LDF model is shown in Eq. 6:

$\frac{q}{q_{e}}=1-e^{-k_{L} t}$

Where $q$ is the adsorption capacity at time $t(\mathrm{mg} / \mathrm{g}), q_{e}$ is the adsorption capacity at equilibrium $(\mathrm{mg} / \mathrm{g}), \mathrm{k}_{L}$ is the effective mass transfer coefficient $(1 / \mathrm{h})$, and $t$ is the time $(\mathrm{h})$. Additionally, the Crank model (Eq. 7) represents the analytical solution of the equation of the Fick's second law, when the external mass transfer resistance is negligible. This model considers that the rate-limiting step is the intraparticle mass transfer, free-solute adsorbent particle, well-stirred solution of limited volume, and uniform solute concentration. In Eq. (7), the total amount of solute adsorbed after time $t$ is related to the total amount of solute adsorbed after infinite time (i.e. at equilibrium) as follows:

$$
\frac{q}{q_{e}}=1-\sum_{n=1}^{\infty} \frac{6 \alpha(\alpha+1) \exp \left(-D_{s} q_{n}^{2} t / d^{2}\right.}{9+9 \alpha+q_{n}^{2} \alpha^{2}}
$$

where $q$ is the adsorption capacity at time $t(\mathrm{mg} / \mathrm{g}), q_{e}$ is the adsorption capacity at equilibrium $(\mathrm{mg} / \mathrm{g}), d$ is the diameter of the particle $(\mathrm{m}), D_{s}$ is the effective diffusion coefficient $\left(\mathrm{m}^{2} / \mathrm{h}\right)$, and $\mathrm{t}$ is the time (h). $\alpha$ is the effective volume ratio and is expressed 
in terms of the final uptake of solute by Eq. (8), $\mathrm{q}_{\mathrm{n}}$ represent the non-zero solutions of Eq. (9):

$\tan q_{n}=\frac{3 q_{n}}{3+\alpha q_{n}^{2}}$

$\frac{q_{e}}{V C_{o}}=\frac{1}{1+\alpha}$

The parameters of the isotherm and kinetics models were obtained by non-linear regression, the Solver ${ }^{\circledR}$ tool of Microsoft Excel was used to minimize the standard error (Eq. 10), and the coefficient of determination $\left(R^{2}\right)$ was also calculated by Eq. 11 .

$S E=\sqrt{\frac{\left(q_{e, e x p}-q_{e, c a l}\right)^{2}}{n-(k+1)}}$

$R^{2}=\frac{\sum\left(q_{e, c a l}-\bar{q}_{e, e x p}\right)^{2}}{\sum\left(q_{e, c a l-\bar{q}_{e, e x p}}\right)^{2}+\sum\left(q_{e, c a l}-q_{e, \text { exp }}\right)^{2}}$

Where $q_{e, c a l}$ is the adsorption capacity at equilibrium calculated by the kinetic model $(\mathrm{mg} / \mathrm{g}), q_{e, \exp }$ is the adsorption capacity at equilibrium from experimental data $(\mathrm{mg} / \mathrm{g})$, $\bar{q}_{e, \exp }$ is the average adsorption capacity at equilibrium obtained from the experimental data $(\mathrm{mg} / \mathrm{g}), n$ is the number of experimental data, and $k$ is the number of the model parameters.

\subsection{Removal cost analysis}

A simple calculation of the cost associated with the EP and activated carbon usage for the removal of siloxane was performed. First, the adsorbent mass per hour $\left(\dot{m}_{a d s}\right)$ was calculated by considering the adsorption capacity $(q)$ of each adsorbent, the siloxane concentration $(C)$, and the biogas flow rate of $1 \mathrm{~m}^{3} / \mathrm{h}\left(\mathrm{Q}_{\mathrm{bg}}\right)$, as shown in Eq. (12). Then, the cost of the usage of EP and activated carbon was obtained from Eq. (13).

$\dot{m}_{a d s}=\left(Q_{b g}\right)(C) / q$ 
$\operatorname{cost}=\left(\dot{m}_{a d s}\right)\left(p_{a d s}\right) / \varepsilon_{b g}$

where $p_{\text {ads }}$ is the price of the adsorbent, and $\varepsilon_{\mathrm{bg}}$ is the amount of electricity generated from biogas.

\section{Results and discussion}

\subsection{Perlite characterization}

The examination of the crystalline structure of RP and EP were determined by X-ray diffraction analysis (Figure 1). A broad peak was observed, centered at 25 degrees (20), related to the absence of any ordered crystalline structure. Thus, this material could be considered mainly amorphous (Celik et al., 2013). The surface functional groups were determined by FTIR analysis (Figure 2). A broad band around $3500 \mathrm{~cm}^{-1}$ (A) was identified, and it is attributed to the stretching mode of $\mathrm{O}-\mathrm{H}$ groups. In comparison, the band at $1630 \mathrm{~cm}^{-1}$ (B) is characteristic of the bending mode of $\mathrm{OH}$ groups of $\mathrm{Si}-\mathrm{OH}$ and water molecules adsorbed on the perlite surface. The band at $1386 \mathrm{~cm}^{-1}$ (C) corresponds to the $\mathrm{C}-\mathrm{H}$ deformation of $\mathrm{CH}_{2}$ and $\mathrm{CH}_{3}$ groups (Liu and Huang, 2002). On the other hand, lower intensity bands were observed at $1200-1000 \mathrm{~cm}^{-1}(D)$ and $800 \mathrm{~cm}^{-}$ ${ }^{1}$ (E) related to the Si-O vibrations of asymmetric Si-O-Si stretching and the Si-O vibrations of symmetric stretching of Si-O-Al. 


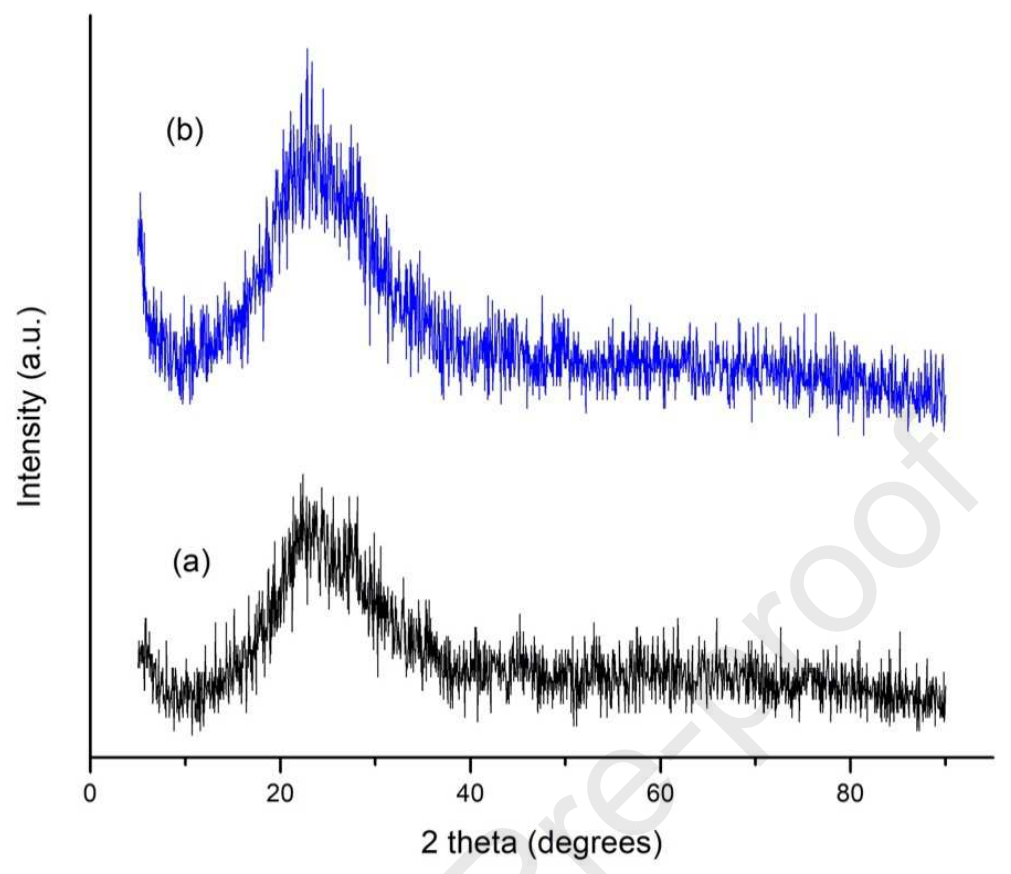

Figure 1. X-ray diffraction patterns of a) raw perlite and b) expanded perlite. 


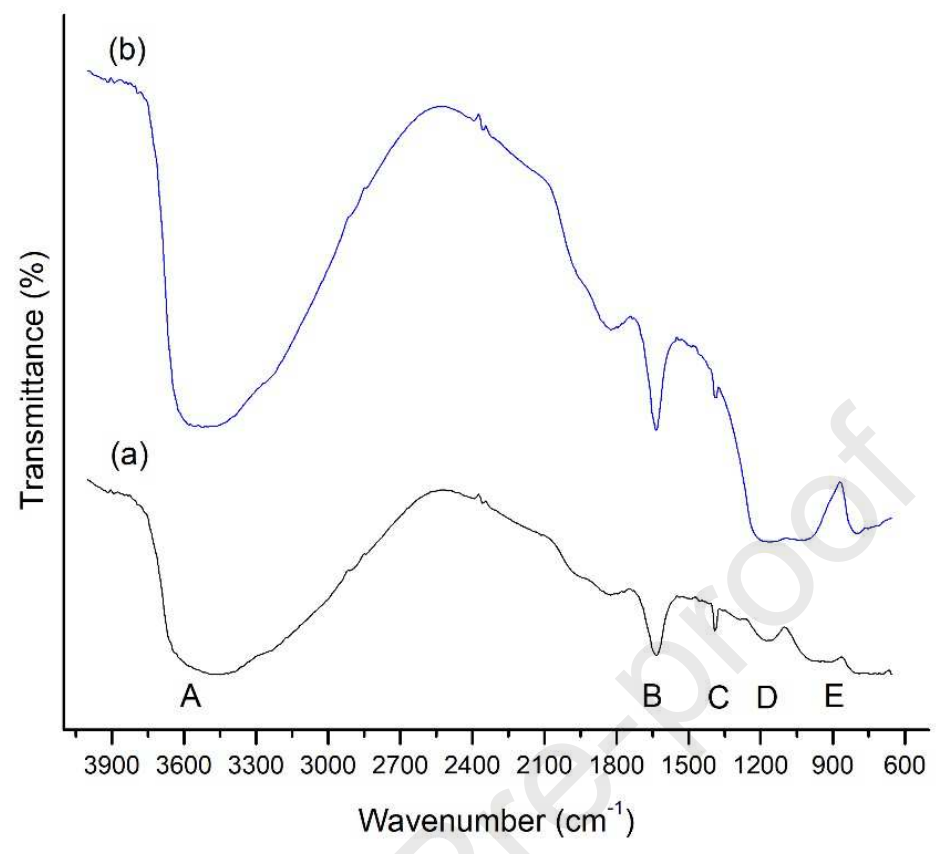

Figure 2. Fourier transform infrared spectra of the (a) raw perlite and (b) expanded perlite.

According to Figure 2, the intensity of the absorption bands A, B, C, and E on the EP surface was more significant than that shown by RP. This behavior could be attributed to the increase in the exposure of the silanol functional groups after the thermal expansion process of RP. Silanol groups have been described as adsorption sites for polar molecules, such as D4, which suggests that both adsorbent materials may exhibit a potential adsorption capacity of D4 (Sigot et al., 2014).

Also, SEM was used to analyze the morphology and texture of RP and EP (Figure 3). In general, RP and EP have a rough outer surface and a white vitreous luster due to its amorphous silica content. Moreover, the RP micrograph (Figure 3 left) reveals a rough surface with slits of a few micrometers in diameter $(<10 \mu \mathrm{m})$. On the contrary, EP 
exhibits shallow grooves about $20-100 \mu \mathrm{m}$ formed by smooth leaves (Figure 3 right) due to the high temperatures exposition (800-1000 $\left.{ }^{\circ} \mathrm{C}\right)$ during the thermal expansion process.

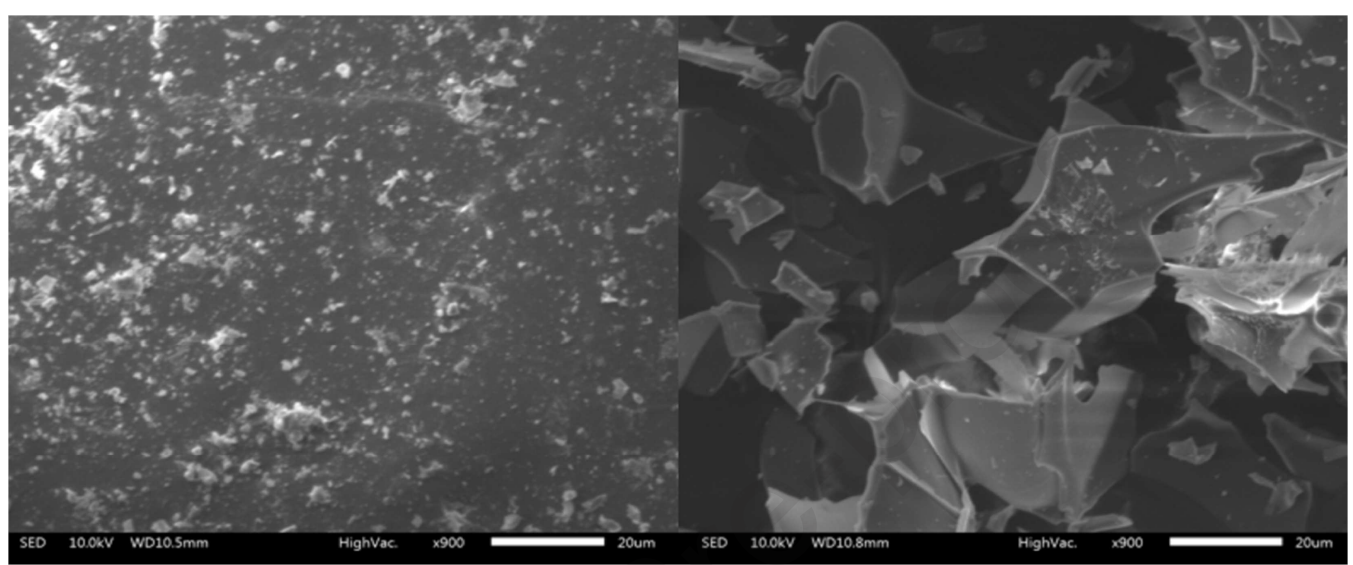

Figure 3. Scanning electron microscopy images of raw perlite (left) and expanded perlite (right).

SEM/EDS was used to investigate the chemical elements on the surface of RP and EP. The most abundant chemical elements in both materials are oxygen $(\mathrm{O})$, silicon $(\mathrm{Si})$ and aluminum (Al), in the form of silicon dioxide and aluminum dioxide (see Table 1). Additionally, TGA was used to determine the thermal stability of RP and EP (Figure 4). The TGA curve of RP showed a continuous decrease in weight in the range of (50-800) ${ }^{\circ} \mathrm{C}$. The weight loss over the range temperature from 50 to $120{ }^{\circ} \mathrm{C}$ is due to the elimination of the water absorbed on the surface (loss of $0.11 \%$ ) and the weight loss observed up to $800^{\circ} \mathrm{C}$ (approximately $3.43 \%$ ) can be attributed to the dehydroxylation of the silanol groups (Roulia et al., 2006). 


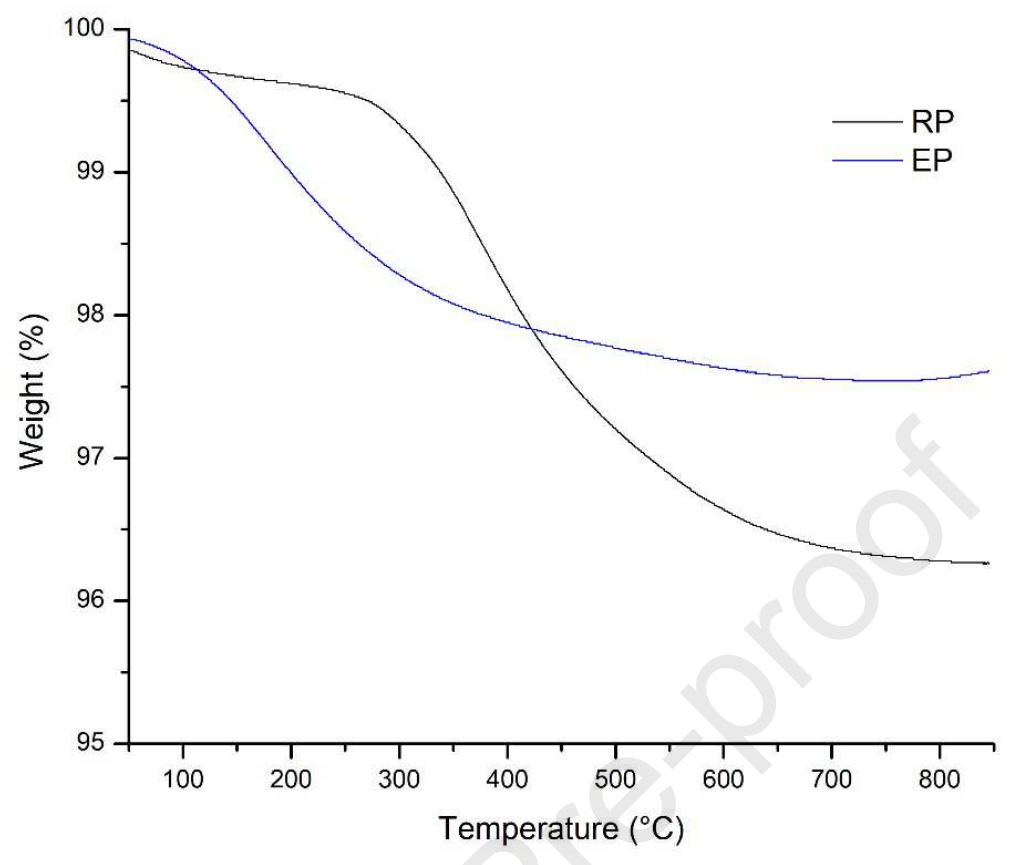

Figure 4. Thermogravimetric analysis curve for (a) raw perlite and (b) expanded perlite.

Table 1. Relative elementary composition of raw perlite and expanded perlite.

\begin{tabular}{ccc}
\hline Element & $\begin{array}{c}\text { Raw perlite } \\
\text { (\% weight) }\end{array}$ & $\begin{array}{c}\text { Expanded } \\
\text { perlite } \\
\text { (\% weight) }\end{array}$ \\
\hline $\mathbf{O}$ & 56.84 & 55.98 \\
$\mathbf{M g}$ & 0.56 & 0.00 \\
$\mathbf{A l}$ & 5.18 & 5.64 \\
$\mathbf{S i}$ & 23.17 & 31.81 \\
$\mathbf{K}$ & 3.02 & 4.16 \\
$\mathbf{C a}$ & 0.22 & 0.00 \\
$\mathrm{Ti}$ & 0.83 & 0.00 \\
$\mathbf{F e}$ & 13.91 & 0.00 \\
$\mathrm{Na}$ & 0.87 & 2.41 \\
\hline
\end{tabular}


The density of the silanol groups was calculated to quantify the dehydroxylation of EP after been subjected to thermal expansion. The weight loss of RP and EP was associated to the condensation of the silanol groups distributed on the surface of the adsorbents (de Farias and Airoldi, 1998). The density of the silanol group was 2515.43 $\mathrm{OH} / \mathrm{nm}^{2}$ and $653.75 \mathrm{OH} / \mathrm{nm}^{2}$ for $\mathrm{RP}$ and $\mathrm{EP}$, respectively, showing that the dehydroxylation process decreases 3.85 folds the number of silanol groups. Due to the higher amount of silanol groups on the surface of the RP, a greater siloxane adsorption capacity in this material would be expected when compared with the adsorption capacity of the EP.

The specific surface area was determined by $\mathrm{N}_{2}$ adsorption-desorption on RP and EP (Figure S2). The adsorption isotherms of RP and EP are type IV (IUPAC classification), which are characteristic of mesoporous materials. The specific surface obtained by the BET method for EP was $2.12 \mathrm{~m}^{2} / \mathrm{g}$, which is twice the value of $\operatorname{RP}\left(1.2 \mathrm{~m}^{2} / \mathrm{g}\right)$. Again, the increase in the surface area is due to the expansion process of RP when subjected to high temperatures (above $700^{\circ} \mathrm{C}$ ).

The mean pore size of RP and EP is $47.13 \AA$ and $43.42 \AA$ (Figure S3), respectively, whereas the D4 molecule size is approximately $10 \AA$. Thus, no resistance to intraparticle diffusion is expected (Jiang et al., 2016).

\subsection{Adsorption Equilibrium}

The adsorption capacity at equilibrium was determined as a function of the D4 equilibrium concentration, the adsorption isotherms of RP and EP were carried out with 
a fixed amount of $0.154 \mathrm{~g}$ of adsorbent, temperature of $25 \stackrel{\circ}{\circ}, 1$ atm, and an initial concentration of D4 from 80 to $450 \mathrm{mg} / \mathrm{m}^{3}$.

This study was carried out at low D4 concentration, similar to the values found in biogas streams at WWTP and landfills (Bak et al., 2019; Tran et al., 2019b). At low concentration, the adsorption isotherms of D4 exhibited a linear behavior, which was described by Henry's Law model (Figure 5). The values of the Henry constant for D4 adsorption on RP and EP were 0.1023 and $0.1359 \mathrm{~m}^{3} \mathrm{D} 4 / \mathrm{g}$, respectively. The $\mathrm{R}^{2}$ values of Henry model for RP and EP were 0.980 and 0.972 , respectively. These results could be an indication of a stronger affinity between EP and D4 than to RP since the Henry constant is a measure of the interaction between a molecule and the functional groups in the adsorbent solid.

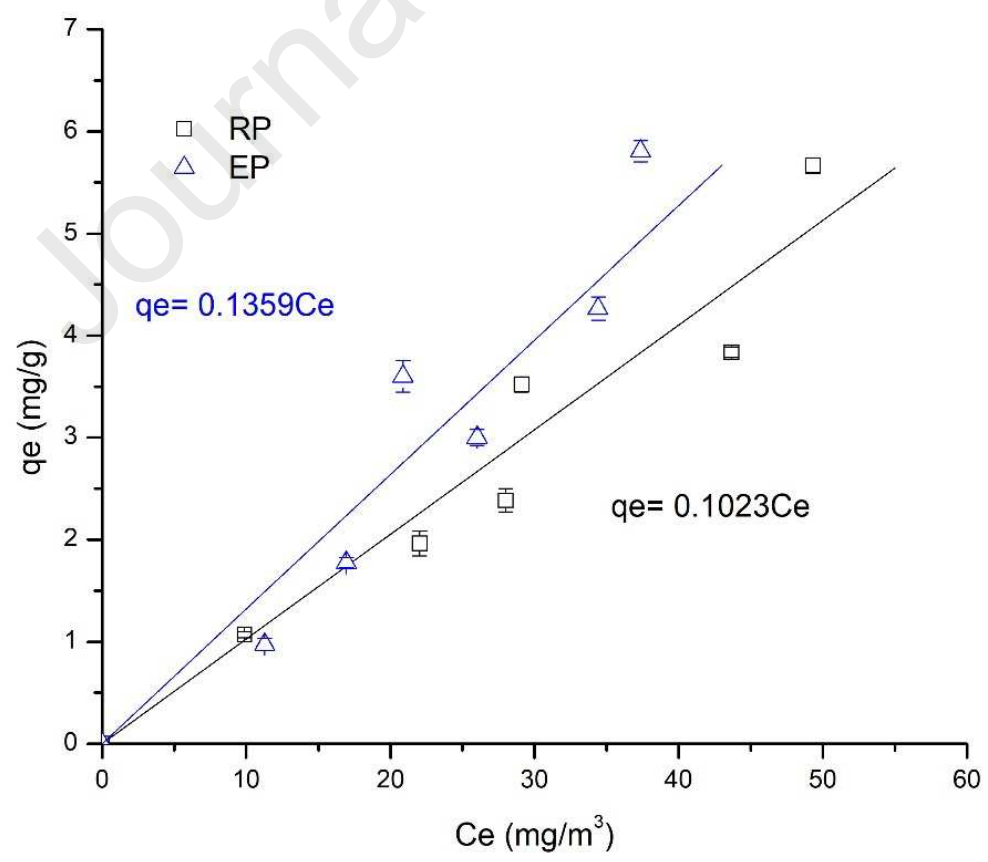


Figure 5. Adsorption isotherm of D4 on raw perlite $(\square)$ and expanded perlite $(\bigcirc)$. The solid lines represent the Henry Isotherm model. Error bars represent standard deviation of triplicate measurements.

In contrast, most studies of the siloxanes dynamic adsorption experiments have been carried out at higher siloxanes concentrations than those commonly found in real biogas samples. This is to shorten the contact time in the adsorption experiments (CabreraCodony et al., 2018; Tran et al., 2019a). The same applies to the few experiments performed in batch systems (Nam et al., 2013), which prevents comparison between the adsorption capacity of perlite with other materials already reported (see Table 2).

Table 2. Equilibrium adsorption capacities of several adsorbents reported for the removal of siloxane D4.

\begin{tabular}{|c|c|c|c|c|}
\hline $\begin{array}{c}\text { System } \\
\text { Configuration }\end{array}$ & Adsorbent & $\begin{array}{c}\text { Siloxane } \\
\text { concentration } \\
\left(\mathrm{mg} / \mathrm{m}^{3}\right)\end{array}$ & $\begin{array}{l}\text { Equilibrium adsorption } \\
\text { capacity } \\
(\mathrm{mg} / \mathrm{g})\end{array}$ & Reference \\
\hline Dynamic & Activated carbon & $559^{*}$ & 404 & (Oshita et al., 2010) \\
\hline Batch & $\begin{array}{l}\text { Activated carbon } \\
\text { Silica gel } \\
\text { Alumina oxide }\end{array}$ & 7140 & $\begin{array}{l}90 \\
56 \\
34\end{array}$ & (Nam et al., 2013) \\
\hline Dynamic & $\begin{array}{l}\text { Activated carbon } \\
\text { 13X Zeolite } \\
\text { Silica gel }\end{array}$ & 400 & $\begin{array}{r}52 \\
113 \\
216\end{array}$ & (Sigot et al., 2014) \\
\hline Dynamic & Activated carbon & 1540 & 319.9 & $\begin{array}{c}\text { (Cabrera-Codony et } \\
\text { al., 2018) }\end{array}$ \\
\hline Batch & Activated carbon & $164000^{*}$ & 577 & (Santos-Clotas et \\
\hline
\end{tabular}




\begin{tabular}{|c|c|c|c|c|}
\hline & & & & al., 2019) \\
\hline Bench-scale & $\begin{array}{c}\text { Iron oxide } \\
\text { Iron oxide hydroxide } \\
\text { Activated carbon } \\
\text { Silica gel } \\
\text { Zeolite }\end{array}$ & $1822^{*}$ & $\begin{array}{c}1.86 \\
1.33 \\
5.35 \\
1055.32 \\
1.73 \\
\end{array}$ & (Bak et al., 2019) \\
\hline Dynamic & Activated carbon & 12145 & 273 & (Tran et al., 2019a) \\
\hline Dynamic & Activated carbon & 12000 & 269 & (Tran et al., 2019b) \\
\hline Dynamic & $\begin{array}{c}\text { Silica gel } \\
\text { Modified silica gel }\end{array}$ & 83820 & $\begin{array}{l}236.2 \\
367.1\end{array}$ & (Meng et al., 2020) \\
\hline Batch & $\begin{array}{c}\text { Raw perlite } \\
\text { Expanded perlite } \\
\text { Activated carbon } \\
\text { Silica gel }\end{array}$ & 450 & $\begin{array}{l}5.6 \\
5.8 \\
6.8 \\
6.6\end{array}$ & This work \\
\hline
\end{tabular}

Accordingly, the removal of D4 by silica gel and activated carbon were performed under the same conditions previously described in Section 2.2. The adsorption capacities of siloxane D4 followed this order: activated carbon $(6.8 \mathrm{mg} / \mathrm{g})>$ silica gel $(6.6 \mathrm{mg} / \mathrm{g})>$ expanded perlite $(5.8 \mathrm{mg} / \mathrm{g})>$ raw perlite $(5.6 \mathrm{mg} / \mathrm{g})$. The results showed that the EP adsorption capacity is on average about 0.88 and 0.86 times the adsorption capacities of silica gel and activated carbon, respectively (Figure 6). These differences are mainly attributed to the specific surface area of the adsorbent materials (Oshita et al., 2010). The specific surface area of silica gel is $749.62 \mathrm{~m}^{2} / \mathrm{g}$, and the specific surface area of activated carbon is $1240.0 \mathrm{~m}^{2} / \mathrm{g}$ (Delage et al., 2000), which are much larger values than those corresponding to $\operatorname{RP}\left(1.2 \mathrm{~m}^{2} / \mathrm{g}\right)$ and EP $\left(2.12 \mathrm{~m}^{2} / \mathrm{g}\right)$. The specific surface 
area of EP could explain why it had a slightly higher siloxane adsorption capacity than the RP. Moreover, it is assumed that the density of silanol groups on the RP and EP surface is not directly proportional to the adsorption capacity of siloxanes at low region D4 concentration.

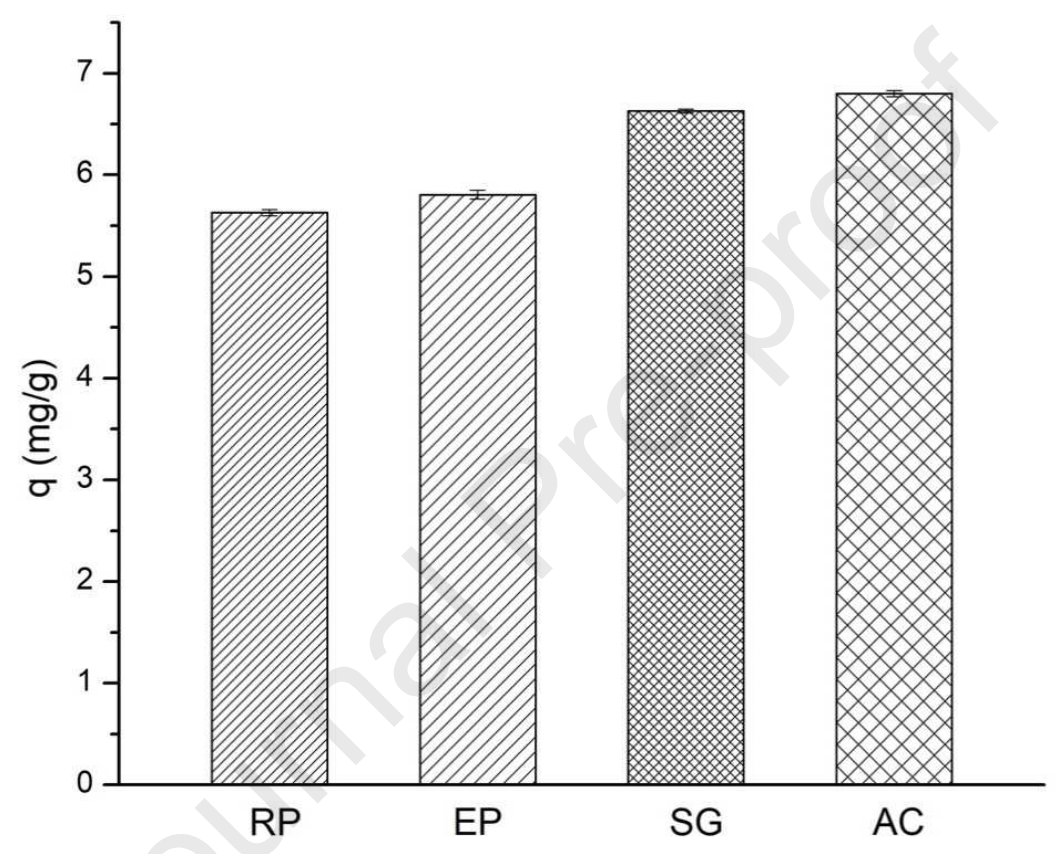

Figure 6. Equilibrium adsorption capacity of raw perlite (RP), expanded perlite (EP), silica gel (SG), and activated carbon (AC). Experimental conditions: $0.154 \mathrm{~g}$ adsorbent mass, $25 \stackrel{\circ}{\circ} \mathrm{C}, 450 \mathrm{mg} / \mathrm{m}^{3} \mathrm{D} 4$ initial concentration. Error bars represent standard deviation of triplicate measurements.

\subsection{Adsorption Kinetics}

The adsorption kinetics of D4 on RP and EP were performed using $0.15 \mathrm{~g}$ of each adsorbent in a batch system at $25{ }^{\circ} \mathrm{C}, 1 \mathrm{~atm}$, and initial concentration of D4 from (80- 
450) $\mathrm{mg} / \mathrm{m}^{3}$. As can be seen in Figure 7 , there is a rapid increase in the adsorption capacity in the first $10 \mathrm{~h}$ for both adsorbents, followed by a slower increase until reaching a plateau in approximately $170 \mathrm{~h}$. Additionally, an increase in the adsorption capacity is observed as the initial concentration of D4 rises, while the equilibrium time does not depend on the initial concentration. Therefore, the equilibrium time is the same for all studied experiments at different initial concentrations. For instance, at $80 \mathrm{mg} / \mathrm{m}^{3}$, the equilibrium adsorption capacities were $1.06 \mathrm{mg} \mathrm{D} 4 / \mathrm{g}$ and $0.97 \mathrm{mg} \mathrm{D} 4 / \mathrm{g}$ for RP and $E P$, respectively; wshile at $450 \mathrm{mg} / \mathrm{m}^{3}$, an increase in the equilibrium adsorption capacities of $81 \%$ and $83.3 \%$ were obtained for RP and EP, respectively. As the initial D4 concentration increases, the number of active sites occupied on the perlite surface increments as well, causing an increase of the adsorption capacity. It is important to mention that long time is required for RP and EP to achieve equilibrium (170 h), which can be due to the low specific surface area $\left(<2 \mathrm{~m}^{2} / \mathrm{g}\right)$. Nevertheless, these low-cost materials can reduce the siloxane D4 concentration to values lower than the recommended by leading manufacturers $\left(<28 \mathrm{mg} / \mathrm{m}^{3}\right)($ Gaj, 2017). 

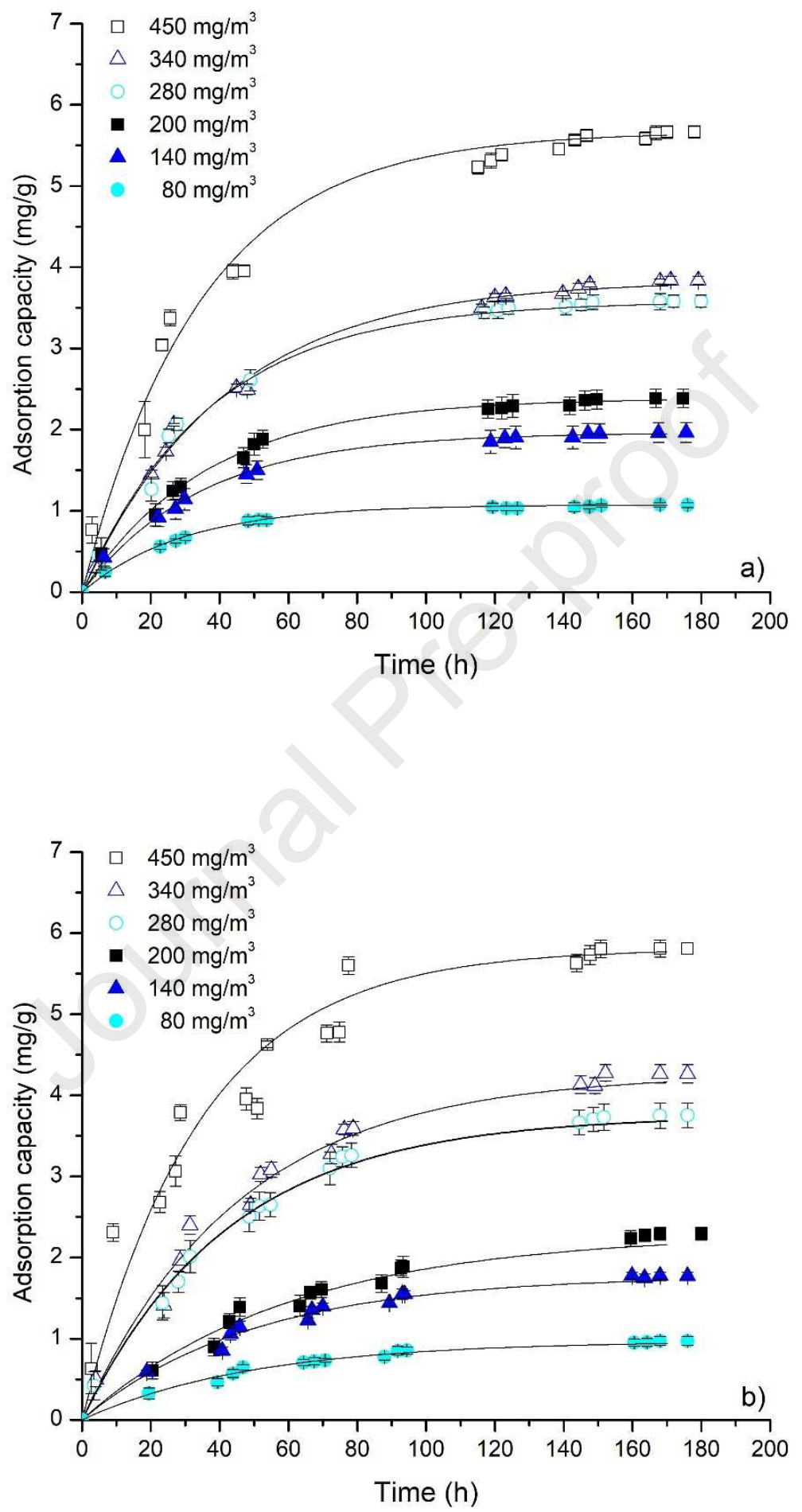
Figure 7. Adsorption kinetics of siloxane D4 onto (a) raw perlite and (b) expanded perlite

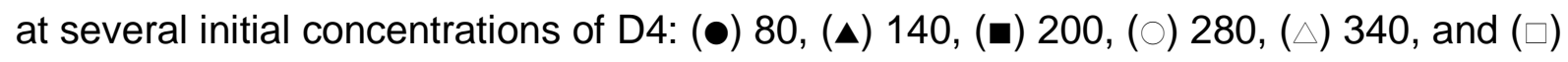
$450 \mathrm{mg} / \mathrm{m}^{3}$. Solid lines represent the fitting results of the LDF model.

On the other hand, four mathematical models, including the Elovich, Ritchie, LDF, and Crank models were tested to predict the adsorption kinetics of D4 onto RP and EP. The standard error, coefficient of determination, and the model parameters are listed in Tables 3 and 4 for the adsorption of D4 onto RP and EP, respectively. The Elovich model is a well-known kinetics model that describes the adsorption kinetics of gas molecules on solids. Although it has been applied to describe chemisorption kinetics, the phenomena behind the equation are related to the linear increase in the activation energy for adsorption with the surface coverage of the adsorbent. The standard errors and coefficients of determination obtained by the Elovich model are in the range of 0.059-0.336 and 0.970-0.990, respectively. These high values can be due to the fact that this model have two adjustable parameters. In contrast, when the Crank model was used, the adsorption kinetics data exhibited the highest SE values, suggesting that the adsorption of D4 onto RP and EP are not controlled by internal mass transfer. Similarly, the Ritchie model does not predict well the adsorption kinetics data according to the low $R^{2}$ obtained values. On the other hand, the LDF model present the highest $R^{2}(0.974-$ 0.993) and the lowest SE values (0.016-0.404) indicating that the mass transfer is the rate-controlling step.

Table 3. Parameters of adsorption kinetic models of siloxane D4 onto raw perlite. 


\begin{tabular}{|c|c|c|c|c|c|}
\hline \multicolumn{6}{|c|}{ Elovich Model } \\
\hline $\mathrm{Co}\left(\mathrm{mg} / \mathrm{m}^{3}\right)$ & to $(\mathrm{h})$ & $a(\mathrm{mg} / \mathrm{g} \cdot \mathrm{h})$ & $\mathrm{b}(\mathrm{g} / \mathrm{mg})$ & SE & $\mathrm{R}^{2}$ \\
\hline 80 & $3.742( \pm 1.290)$ & $0.078( \pm 0.020)$ & $3.411( \pm 0.246)$ & 0.059 & 0.974 \\
\hline 140 & $5.236( \pm 1.891)$ & $0.111( \pm 0.032)$ & $1.722( \pm 0.060)$ & 0.067 & 0.991 \\
\hline 200 & $6.034( \pm 3.414)$ & $0.122( \pm 0.044)$ & $1.360( \pm 0.143)$ & 0.105 & 0.985 \\
\hline 280 & $8.331( \pm 1.522)$ & $0.147( \pm 0.019)$ & $0.819( \pm 0.032)$ & 0.194 & 0.982 \\
\hline 340 & $10.519( \pm 1.758)$ & $0.133( \pm 0.014)$ & $0.716( \pm 0.035)$ & 0.149 & 0.990 \\
\hline 450 & $4.802( \pm 1.086)$ & $0.335( \pm 0.051)$ & $0.621( \pm 0.046)$ & 0.225 & 0.988 \\
\hline \multicolumn{6}{|c|}{ Ritchie Model } \\
\hline $\mathrm{Co}\left(\mathrm{mg} / \mathrm{m}^{3}\right)$ & & $k_{R}(1 / h)$ & & SE & $\mathrm{R}^{2}$ \\
\hline 80 & & $0.061( \pm 0.008)$ & & 0.090 & 0.923 \\
\hline 140 & & $0.052( \pm 0.006)$ & & 0.178 & 0.920 \\
\hline 200 & & $0.049( \pm 0.007)$ & & 0.226 & 0.908 \\
\hline 280 & & $0.045( \pm 0.003)$ & & 0.416 & 0.888 \\
\hline 340 & & $0.040( \pm 0.002)$ & & 0.413 & 0.895 \\
\hline 450 & & $0.053( \pm 0.004)$ & & 0.504 & 0.925 \\
\hline \multicolumn{6}{|c|}{ LDF Model } \\
\hline $\mathrm{Co}\left(\mathrm{mg} / \mathrm{m}^{3}\right)$ & & $k_{L}(1 / h)$ & & SE & $\mathrm{R}^{2}$ \\
\hline 80 & & $0.034( \pm 0.003)$ & & 0.016 & 0.998 \\
\hline 140 & & $0.029( \pm 0.002)$ & & 0.038 & 0.997 \\
\hline 200 & & $0.027( \pm 0.001)$ & & 0.059 & 0.995 \\
\hline 280 & & $0.027( \pm 0.001)$ & & 0.101 & 0.994 \\
\hline 340 & & $0.024( \pm 0.001)$ & & 0.092 & 0.996 \\
\hline 450 & $\Delta$ & $0.029( \pm 0.002)$ & & 0.216 & 0.989 \\
\hline \multicolumn{6}{|c|}{ Crank Model } \\
\hline $\mathrm{Co}\left(\mathrm{mg} / \mathrm{m}^{3}\right)$ & & Ds $\left(\mathrm{m}^{2} / \mathrm{h}\right)$ & & SE & $\mathrm{R}^{2}$ \\
\hline 80 & 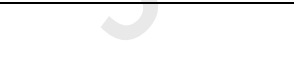 & $1.29 \times 10^{-9}$ & & 0.323 & 0.624 \\
\hline 140 & & $1.29 \times 10^{-9}$ & & 0.679 & 0.771 \\
\hline 200 & & $1.29 \times 10^{-9}$ & & 0.803 & 0.827 \\
\hline 280 & & $1.29 \times 10^{-9}$ & & 1.285 & 0.843 \\
\hline 340 & & $1.29 \times 10^{-9}$ & & 1.379 & 0.889 \\
\hline 450 & & $1.29 \times 10^{-9}$ & & 1.883 & 0.913 \\
\hline
\end{tabular}

a, to, and b: Elovich constants, $\mathrm{K}_{\mathrm{R}}$ : Ritchie kinetic rate constant, $\mathrm{K}_{\mathrm{L}}$ : effective mass transfer coefficient, $\mathrm{D}_{\mathrm{s}}$ : effective diffusion coefficient, Co: D4 initial concentration, SE: standard error, $\mathrm{R}^{2}$ : coefficient of determination. The standard deviations are reported in parentheses.

Table 4. Parameters of adsorption kinetic models of siloxane D4 onto expanded perlite.

\begin{tabular}{llllll}
\hline \multicolumn{7}{c}{ Elovich Model } \\
Co $\left(\mathrm{mg} / \mathrm{m}^{3}\right)$ & to $(\mathrm{h})$ & $\mathrm{a}(\mathrm{mg} / \mathrm{g} \cdot \mathrm{h})$ & $\mathrm{b}(\mathrm{g} / \mathrm{mg})$ & SE & $\mathrm{R}^{2}$ \\
\hline
\end{tabular}




\begin{tabular}{|c|c|c|c|c|c|}
\hline 80 & $11.824( \pm 3.608)$ & $0.031( \pm 0.006)$ & $2.736( \pm 0.159)$ & 0.044 & 0.980 \\
\hline 140 & $12.870( \pm 1.117)$ & $0.052( \pm 0.005)$ & $1.493( \pm 0.035)$ & 0.075 & 0.982 \\
\hline 200 & $24.314( \pm 6.559)$ & $0.046( \pm 0.010)$ & $0.887( \pm 0.074)$ & 0.110 & 0.979 \\
\hline 280 & $9.350( \pm 3.985)$ & $0.143( \pm 0.041)$ & $0.750( \pm 0.072)$ & 0.186 & 0.981 \\
\hline 340 & $10.830( \pm 2.357)$ & $0.146( \pm 0.023)$ & $0.634( \pm 0.040)$ & 0.229 & 0.978 \\
\hline 450 & $4.209( \pm 1.582)$ & $0.384( \pm 0.123)$ & $0.618( \pm 0.064)$ & 0.356 & 0.970 \\
\hline \multicolumn{6}{|c|}{ Ritchie Model } \\
\hline Co $\left(\mathrm{mg} / \mathrm{m}^{3}\right)$ & & $\mathrm{k}_{\mathrm{R}}(1 / \mathrm{h})$ & & SE & $\mathrm{R}^{2}$ \\
\hline 80 & & $0.038( \pm 0.003)$ & & 0.097 & 0.868 \\
\hline 140 & & $0.038( \pm 0.001)$ & & 0.186 & 0.859 \\
\hline 200 & & $0.028( \pm 0.003)$ & & 0.278 & 0.814 \\
\hline 280 & & $0.041( \pm 0.005)$ & & 1.787 & 0.828 \\
\hline 340 & & $0.038( \pm 0.003)$ & & 0.451 & 0.884 \\
\hline 450 & & $0.055( \pm 0.005)$ & & 0.531 & 0.929 \\
\hline \multicolumn{6}{|c|}{ LDF Model } \\
\hline Co $\left(\mathrm{mg} / \mathrm{m}^{3}\right)$ & & $\mathrm{k}_{\mathrm{L}}(1 / \mathrm{h})$ & 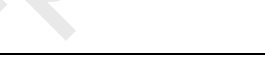 & SE & $\mathrm{R}^{2}$ \\
\hline 80 & & $0.020\left( \pm 7.39 \times 10^{-4}\right)$ & & 0.034 & 0.987 \\
\hline 140 & & $0.020\left( \pm 4.86 \times 10^{-4}\right)$ & & 0.072 & 0.983 \\
\hline 200 & & $0.017\left( \pm 1.22 \times 10^{-3}\right)$ & & 0.118 & 0.972 \\
\hline 280 & & $0.023\left( \pm 1.64 \times 10^{-3}\right)$ & & 0.091 & 0.995 \\
\hline 340 & & $0.022\left( \pm 8.67 \times 10^{-4}\right)$ & & 0.161 & 0.987 \\
\hline 450 & & $0.029\left( \pm 1.27 \times 10^{-3}\right)$ & & 0.404 & 0.962 \\
\hline \multicolumn{6}{|c|}{ Crank Model } \\
\hline Co $\left(\mathrm{mg} / \mathrm{m}^{3}\right)$ & 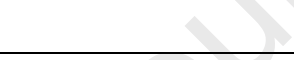 & $\mathrm{Ds}\left(\mathrm{m}^{2} / \mathrm{h}\right)$ & & SE & $\mathrm{R}^{2}$ \\
\hline 80 & & $1.37 \times 10^{-9}$ & & 0.314 & 0.686 \\
\hline 140 & & $1.37 \times 10^{-9}$ & & 0.574 & 0.795 \\
\hline 200 & & $1.37 \times 10^{-9}$ & & 0.838 & 0.869 \\
\hline 280 & & $1.37 \times 10^{-9}$ & & 1.459 & 0.918 \\
\hline 340 & & $1.37 \times 10^{-9}$ & & 1.653 & 0.921 \\
\hline 450 & & $1.37 \times 10^{-9}$ & & 1.885 & 0.914 \\
\hline
\end{tabular}

a, to, and b: Elovich constants, $K_{\mathrm{B}}$ : Ritchie kinetic rate constant, $\mathrm{K}_{\mathrm{L}}$ : effective mass transfer coefficient, $\mathrm{D}_{\mathrm{s}}$ : effective diffusion coefficient, $\mathrm{Co}$ : D4 initial concentration, SE: standard error, $\mathrm{R}^{2}$ : coefficient of determination. The standard deviations are reported in parentheses.

\subsection{Adsorbent Regeneration Studies}

The regeneration process occurs when a spent adsorbent material is subjected to the release of the adsorbed species to recover the adsorption sites, but with the minimum possible alteration of its physicochemical or textural properties. In this study, the 
desorption of D4 from EP by thermal regeneration was evaluated at $200^{\circ} \mathrm{C}$. In Figure 8 , it is observed that the mass of D4 desorbed is $0.08 \mathrm{mg}$, which is equivalent to $40 \%$ of the total amount of D4 adsorbed on EP.

It is reported that during the desorption of D4 on activated carbon and silica gel, a chemical transformation of D4 occurs in cyclic oligomers such as hexamethylcyclotrisiloxane limiting the thermal regeneration due to the closing of pores and therefore the decrease in the adsorption capacity of siloxanes of the regenerated material, consequently, silica gel (Sigot et al., 2015) and activated carbon (Tran et al., 2019a) cannot be used in further adsorption process. In this study, low regeneration time and temperature were needed for the desorption of D4 from EP, suggesting weak interactions between the silanol groups at expanded perlite surface and the siloxane D4.

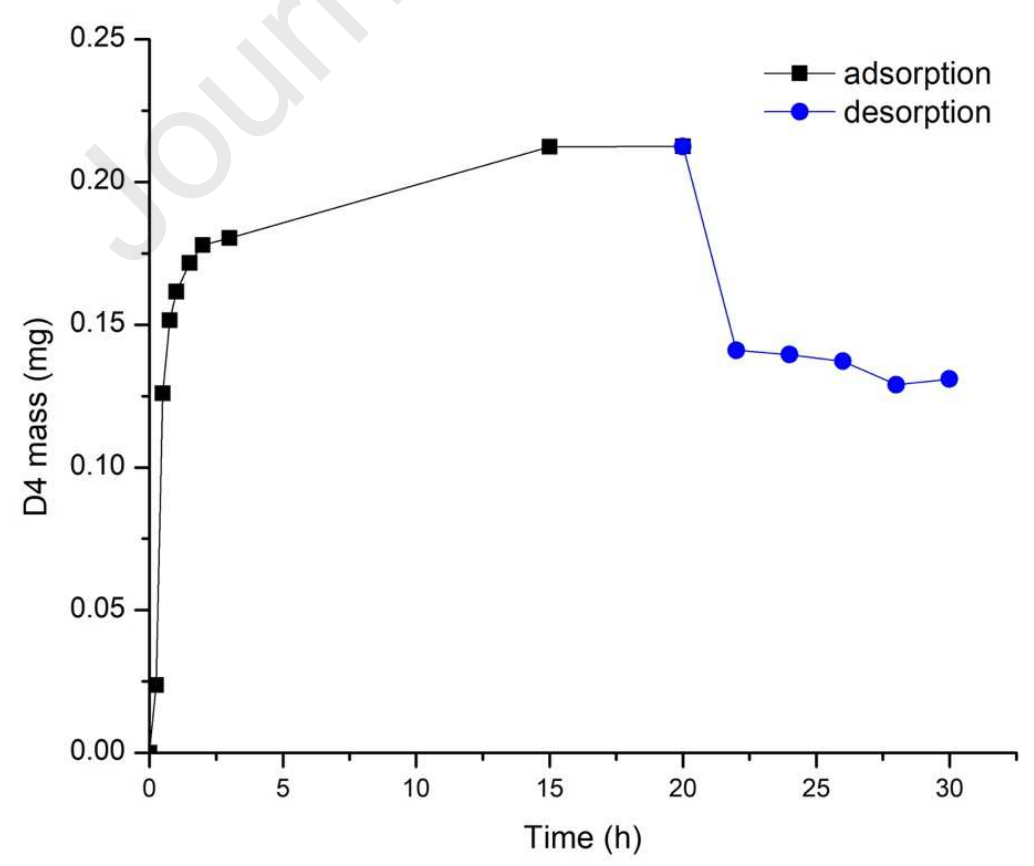


Figure 8. Adsorption-desorption kinetics of siloxane D4 onto expanded perlite. Experimental conditions: $450 \mathrm{mg} / \mathrm{m}^{3} \mathrm{D} 4$ initial concentration, desorption temperature of $200 \stackrel{\circ}{ } \mathrm{C}$.

\subsection{Removal cost analysis}

A simple estimation of the costs associated with the usage of EP and activated carbon for the removal of D4 was made taking into consideration $1 \mathrm{~m}^{3} / \mathrm{h}$ biogas, $130 \mathrm{mg} / \mathrm{Nm}^{3}$ siloxane concentration (a value commonly found in real samples of biogas), the adsorption capacity (5.8 and $6.8 \mathrm{mg} / \mathrm{g}$ for EP and activated carbon (Gupta et al., 2009), respectively), and the price of each material (US\$ $2.18 / \mathrm{kg}$ and US\$ $3.3 / \mathrm{kg}$ for EP and activated carbon, respectively). When the D4 initial concentration is $130 \mathrm{mg} / \mathrm{Nm}^{3}$, the adsorbent mass per hour $\left(\dot{m}_{a d s}\right)$ of activated carbon required for the purification of 1 $\mathrm{m}^{3} / \mathrm{h}$ of biogas is $0.0191 \mathrm{Kg}$ activated carbon/h (obtained by Eq. 13). Since, $1 \mathrm{~m}^{3} / \mathrm{h}$ can be converted to $1.4 \mathrm{kWh}$ of electricity (Mitiku Teferra and Wubu, 2019). Thus, the cost associated to the usage of activated carbon for the removal of $130 \mathrm{mg} / \mathrm{Nm}^{3}$ siloxane is US\$ $0.045 / \mathrm{kWh}$ (by using Eq. 12). In the case of EP, the $\dot{m}_{a d s}$ required is $0.0224 \mathrm{~kg}$ $\mathrm{EP} / \mathrm{h}$ with a cost of US\$ $0.0349 / \mathrm{kWh}$. Although the adsorption capacity of EP is slightly lower than the activated carbon, its low cost contributes to the economy of the purification process. This cost could be reduced by using EP in several adsorption/desorption cycles. It is important to mention that the cost of the thermal regeneration is not included. Hence, further studies need to be conducted to estimate the total cost associated to the siloxane removal from biogas that includes thermal regeneration cost and the reusability of EP. 


\section{Conclusions and future prospects}

In this study, the use of perlite as a low cost and efficient adsorbent for removing siloxane has been demonstrated. The adsorbent characterization analysis revealed the morphological nature of RP and EP as amorphous materials with low specific surface area and mesoporous pore size distribution, but good thermal stability. In addition, silanol functional groups were identified by FTIR analysis, which are described as adsorption sites for siloxanes. Furthermore, it was evidenced that the thermal expansion of EP causes a reduction in the density of silanol groups from 2515.43 to 653.75 $\mathrm{OH} / \mathrm{nm}^{2}$; in contrast, the specific surface area of EP increased two-fold due to the thermal expansion. Also, the isotherm adsorption data were adjusted to Henry's law model at low D4 concentrations. Similar adsorption capacities were obtained for EP, $\mathrm{RP}$, silica gel, and activated carbon in the range of $5.6-6.8 \mathrm{mg} \mathrm{D4} / \mathrm{g}$. The adsorption kinetics followed the LDF model suggesting that the mass transfer is the rate-controlling step. EP could be regenerated at $200^{\circ} \mathrm{C}$ showing fast desorption kinetics, that could represent an advantage over activated carbon which requires temperatures higher than $400 \stackrel{\circ}{\mathrm{C} .}$

As future work, the selectivity in multicomponent gas samples will be assessed on dynamic operation. Also, the increase of the specific surface area of perlite will be investigated by applying physicochemical treatments to enhance the adsorption kinetics rate. Finally, the comparative techno-economical evaluation of the perlite and activated carbon for biogas purification will be carried out by life cycle assessment methodology. 


\section{Data availability}

Datasets related to this article can be found at http://dx.doi.org/10.17632/4gbmztd92j.1, an open-source online data repository hosted at Mendeley Data (Pioquinto-Garcia et al., 2019).

\section{Acknowledgments}

We would like to gratefully acknowledge to Facultad de Ciencias Quimicas, UANL and Consejo Nacional de Ciencia y Tecnologia de Mexico (Scholarship number 604928). Also, we would like to thank Ignacio López-Barro, Edgar Valmaña, and Gerardo Magaña from the company Termolita SAPI de CV for the support provided during the realization of this project.

\section{References}

Ajhar, M., Travesset, M., Yüce, S., Melin, T., 2010. Siloxane removal from landfill and digester gas - A technology overview. Bioresour. Technol. 101, 2913-2923. https://doi.org/10.1016/j.biortech.2009.12.018 Alkan, M., Karadaş, M., Doğan, M., Demirbaş, Ö., 2005. Adsorption of CTAB onto perlite samples from aqueous solutions. J. Colloid Interface Sci. 291, 309-318. https://doi.org/10.1016/J.JCIS.2005.05.027 Altindal, A., Kurt, Ö., Şengül, A., Bekaroǧlu, Ö., 2014. Kinetics of CO2 adsorption on ball-type dicopper phthalocyanine thin film. Sens. Actuators B Chem. 202, 373-381. https://doi.org/10.1016/j.snb.2014.05.107

Álvarez-Flórez, J., Egusquiza, E., 2015. Analysis of damage caused by siloxanes in stationary reciprocating internal combustion engines operating with landfill gas. Eng. Fail. Anal. 50, 29-38. https://doi.org/10.1016/j.engfailanal.2015.01.010 American Biogas Council, 2014. Current and Potential Biogas Production. https://americanbiogascouncil.org/ (accessed 30 January 2019).

Bak, C. u., Lim, C.J., Lee, J.G., Kim, Y.D., Kim, W.S., 2019. Removal of sulfur compounds and siloxanes by physical and chemical sorption. Sep. Purif. Technol. 209, 
542-549. https://doi.org/10.1016/j.seppur.2018.07.080

Cabrera-Codony, A., Santos-Clotas, E., Ania, C.O., Martín, M.J., 2018. Competitive siloxane adsorption in multicomponent gas streams for biogas upgrading. Chem. Eng. J. 344, 565-573. https://doi.org/10.1016/J.CEJ.2018.03.131

Celik, A.G., Kilik, A.M., Cakal, G.O., 2013. Expanded perlite aggregate characterization for use as a lightweight construction raw material. Physicochem. Probl. Miner. Process. 49 685-700 ISSN 2084-4735. https://doi.org/10.5277/ppmp130227

Chaemchuen, S., Zhou, K., Verpoort, F., 2016. From Biogas to Biofuel: Materials Used for Biogas Cleaning to Biomethane. ChemBioEng Rev. 3, 250-265.

https://doi.org/10.1002/cben.201600016

Cooney, D.O., 1998. Adsorption Design for Wastewater Treatment, CRC Press, Florida Crank, John., 1975. The mathematics of diffusion, second ed. Clarendon Press, London De Farias, R.F., Airoldi, C., 1998. Thermogravimetry as a Reliable tool to Estimate the Density of Silanols on a Silica Gel Surface. J. Therm. Anal. Calorim. 53, 751-756. https://doi.org/10.1023/A:1010174224567

Delage, F., Pre, P., Le Cloirec, P., 2000. Mass transfer and warming during adsorption of high concentrations of VOCs on an activated carbon bed: Experimental and theoretical analysis. Environ. Sci. Technol. 34, 4816-4821.

https://doi.org/10.1021/es001187x

Dewil, R., Appels, L., Baeyens, J., 2006. Energy use of biogas hampered by the presence of siloxanes. Energy Convers. Manag. 47, 1711-1722.

https://doi.org/10.1016/j.enconman.2005.10.016

Gaj, K., 2017. Applicability of selected methods and sorbents to simultaneous removal of siloxanes and other impurities from biogas. Clean Technol. Environ. Policy 19, 21812189. https://doi.org/10.1007/s10098-017-1422-1

Giraudet, S., Boulinguiez, B., Le Cloirec, P., 2014. Adsorption and electrothermal desorption of volatile organic compounds and siloxanes onto an activated carbon fiber cloth for biogas purification. Energy Fuels 28, 3924-3932.

https://doi.org/10.1021/ef500600b

Gong, H., Chen, Z., Fan, Y., Zhang, M., Wu, W., Wang, W., 2015. Surface modification of activated carbon for siloxane adsorption. Renew. Energy 83, 144-150.

https://doi.org/10.1016/J.RENENE.2015.04.004

Gupta, V.K., Carrott, P.J.M., Ribeiro Carrott, M.M.L., Suhas, 2009. Low-Cost

adsorbents: Growing approach to wastewater treatmenta review. Crit. Rev. Environ. Sci. Technol. 39, 783-842. https://doi.org/10.1080/10643380801977610

IMTA, 2016. Revisión y actualización del potencial de biomasa para generación de energía eléctrica a partir de plantas de tratamiento de aguas residuales presentado en el Inventario Nacional de Energías Renovables (INERE).

http://repositorio.imta.mx/handle/20.500.12013/1775 (accessed 30 January 2019)

Jiang, T., Zhong, W., Jafari, T., Du, S., He, J., Fu, Y.-J., Singh, P., Suib, S.L., 2016.

Siloxane D4 adsorption by mesoporous aluminosilicates. Chem. Eng. J. 289, 356-364. https://doi.org/10.1016/J.CEJ.2015.12.094

Kapoor, R., Ghosh, P., Tyagi, B., Vijay, V. K., Vijay, V., Thakur, I. S., Kamyab, H., Nguyen, D. D., \& Kumar, A., 2020. Advances in biogas valorization and utilization systems: A comprehensive review. Journal of Cleaner Production, 273, 123052. https://doi.org/10.1016/j.jclepro.2020.123052 
Khoshnevisan, B., Tsapekos, P., Alfaro, N., Díaz, I., Fdz-Polanco, M., Rafiee, S., Angelidaki, I., 2017. A review on prospects and challenges of biological $\mathrm{H} 2 \mathrm{~S}$ removal from biogas with focus on biotrickling filtration and microaerobic desulfurization. Biofuel Res. J. 4, 741-750. https://doi.org/10.18331/BRJ2017.4.4.6

Liu, C., Huang, P.M., 2002. Role of hydroxy-aluminosilicate ions (proto-imogolite sol) in the formation of humic substances. Org. Geochem. 33, 295-305.

https://doi.org/10.1016/S0146-6380(01)00161-9

Matsui, T., Imamura, S., 2010. Removal of siloxane from digestion gas of sewage sludge. Bioresour. Technol. 101, S29-S32.

https://doi.org/10.1016/j.biortech.2009.05.037

Meng, Z.Y., Liu, Y.H., Ma, Z.C., Hou, X.F., 2020. The regulation of micro/mesoporous silica gel by polyethylene imine for enhancing the siloxane removal. Inorg. Chem. Commun. 112, 107754. https://doi.org/10.1016/j.inoche.2019.107754

Mitiku Teferra, D., Wubu, W., 2019. Biogas for Clean Energy, in: Anaerobic Digestion. IntechOpen. https://doi.org/10.5772/intechopen.79534

Nam, S., Namkoong, W., Kang, J.-H., Park, J.-K., Lee, N., 2013. Adsorption characteristics of siloxanes in landfill gas by the adsorption equilibrium test. Waste Manag. 33, 2091-8. https://doi.org/10.1016/j.wasman.2013.03.024

Oshita, K., Ishihara, Y., Takaoka, M., Takeda, N., Matsumoto, T., Morisawa, S., Kitayama, A., 2010. Behaviour and adsorptive removal of siloxanes in sewage sludge biogas. Water Sci. Technol. 61, 2003-2012. https://doi.org/10.2166/wst.2010.101 Poloncarzova, M., Vejrazka, J., Vesely, V., Izak, P., 2011. Effective purification of biogas by a condensing-liquid membrane. Angew. Chem. - Int. Ed. 50, 669-671. https://doi.org/10.1002/anie.201004821

REMBIO, 2012. Producción de biogás en México estado actual y perspectivas, Cuaderno Temático No. 5 Red Mexicana de Bioenergía. http://rembio.org.mx (accessed 30 January 2019).

Ritchie, A.G., 1977. Alternative to the Elovich equation for the kinetics of adsorption of gases on solids. J. Chem. Soc. Faraday Trans. 1 Phys. Chem. Condens. Phases 73, 1650-1653. https://doi.org/10.1039/F19777301650

Roulia, M., Chassapis, K., Kapoutsis, J.A., Kamitsos, E.I., Savvidis, T., 2006. Influence of thermal treatment on the water release and the glassy structure of perlite. J. Mater. Sci. 41, 5870-5881. https://doi.org/10.1007/s10853-006-0325-z Ruiling, G., Shikun, C., Zifu, L., 2017. Research progress of siloxane removal from biogas. Int. J. Agric. Biol. Eng. 10, 30-39. https://doi.org/10.25165/IJABE.V1011.3043 Russo, V., Trifuoggi, M., Di Serio, M., Tesser, R., 2017. Fluid-Solid Adsorption in Batch and Continuous Processing: A Review and Insights into Modeling. Chem. Eng. Technol. 40, 799-820. https://doi.org/10.1002/ceat.201600582

Santos, I.F.S. dos, Gonçalves, A.T.T., Borges, P.B., Barros, R.M., da Silva Lima, R., 2018. Combined use of biogas from sanitary landfill and wastewater treatment plants for distributed energy generation in Brazil. Resour. Conserv. Recycl. 136, 376-388. https://doi.org/10.1016/J.RESCONREC.2018.05.011

Santos-Clotas, E., Cabrera-Codony, A., Ruiz, B., Fuente, E., Martín, M.J., 2019. Sewage biogas efficient purification by means of lignocellulosic waste-based activated carbons. Bioresour. Technol. 275, 207-215.

https://doi.org/10.1016/j.biortech.2018.12.060 
Scarlat, N., Dallemand, J.-F., Fahl, F., 2018. Biogas: Developments and perspectives in Europe. Renew. Energy 129, 457-472. https://doi.org/10.1016/J.RENENE.2018.03.006 Shen, M., Zhang, Y., Hu, D., Fan, J., Zeng, G., 2018. A review on removal of siloxanes from biogas: with a special focus on volatile methylsiloxanes. Environ. Sci. Pollut. Res. https://doi.org/10.1007/s11356-018-3000-4

Sigot, L., Ducom, G., Benadda, B., Labouré, C., 2014. Adsorption of octamethylcyclotetrasiloxane on silica gel for biogas purification. Fuel 135, 205-209. https://doi.org/10.1016/j.fuel.2014.06.058

Sigot, L., Ducom, G., Germain, P., 2015. Adsorption of octamethylcyclotetrasiloxane (D4) on silica gel (SG): Retention mechanism. Microporous Mesoporous Mater. 213, 118-124. https://doi.org/10.1016/j.micromeso.2015.04.016

Sircar, S., Hufton, J.R., 2000. Why does the linear driving force model for adsorption kinetics work? Adsorption 6, 137-147. https://doi.org/10.1023/A:1008965317983

Tabatabaei, M., Aghbashlo, M., Valijanian, E., Kazemi Shariat Panahi, H., Nizami, A.-S., Ghanavati, H., Sulaiman, A., Mirmohamadsadeghi, S., Karimi, K., 2020. A comprehensive review on recent biological innovations to improve biogas production, Part 1: Upstream strategies. Renew. Energy 146, 1204-1220.

https://doi.org/10.1016/j.renene.2019.07.037

Tran, V.T.L., Gélin, P., Ferronato, C., Chovelon, J.M., Fine, L., Postole, G., 2019a. Adsorption of linear and cyclic siloxanes on activated carbons for biogas purification: Sorbents regenerability. Chem. Eng. J. 378, 122152.

https://doi.org/10.1016/j.cej.2019.122152

Tran, V.T.L., Gélin, P., Ferronato, C., Mascunan, P., Rac, V., Chovelon, J.-M., Postole, G., 2019b. Siloxane adsorption on activated carbons: Role of the surface chemistry on sorption properties in humid atmosphere and regenerability issues. Chem. Eng. J. 371, 821-832. https://doi.org/10.1016/J.CEJ.2019.04.087

Ullah Khan, I., Hafiz Dzarfan Othman, M., Hashim, H., Matsuura, T., Ismail, A.F., Rezaei-DashtArzhandi, M., Wan Azelee, I., 2017. Biogas as a renewable energy fuel A review of biogas upgrading, utilisation and storage. Energy Convers. Manag. 150, 277-294. https://doi.org/10.1016/J.ENCONMAN.2017.08.035

United Nations, 2015. Transforming Our World: the 2030 Agenda for Sustainable Development. https://www.unfpa.org/resources/transforming-our-world-2030-agendasustainable-development (accessed 30 January 2019).

Wang, G., Zhang, Z., Hao, Z., 2019. Recent advances in technologies for the removal of volatile methylsiloxanes: A case in biogas purification process. Crit. Rev. Environ. Sci. Technol. 49, 2257-2313. https://doi.org/10.1080/10643389.2019.1607443 Yao, C., Tien, C., 1992. Approximation of intraparticle mass transfer in adsorption processes-I. Linear systems. Chem. Eng. Sci. 47, 457-464.

https://doi.org/10.1016/0009-2509(92)80033-9 
Highlights:

1. The density of silanol groups in perlite decrease $74 \%$ after thermal expansion.

2. Perlite has similar siloxane adsorption capacity than activated carbon and silica gel.

3. A long time is required for perlite to achieved adsorption equilibrium (170 h).

4. Perlite can reduce siloxane concentration to $28 \mathrm{mg} / \mathrm{m}^{3}$ as recommended by manufacturers.

5. Perlite showed fast desorption $(20 \mathrm{~min})$ and a low regeneration temperature $(200 \stackrel{\circ}{\mathrm{C}})$. 


\section{Declaration of interests}

$\bigotimes$ The authors declare that they have no known competing financial interests or personal relationships that could have appeared to influence the work reported in this paper.

$\square$ The authors declare the following financial interests/personal relationships which may be considered as potential competing interests: 